\title{
Inventory Control Analysis Using Economic Order Quantity Method
}

\author{
Rudi Abdullah $^{1 *}$, Samsul Bahari Bahar ${ }^{2}$, Asrianti Dja'wa ${ }^{3}$, La Ode Dedi Abdullah ${ }^{4}$ \\ ${ }^{1}$ Department of Accounting, Faculty of Economics, Buton Muhammadiyah University, Baubau, Indonesia \\ ${ }^{2}$ Department of Civil Engineering, Faculty of Engineering, Buton Muhammadiyah University, Baubau, Indonesia \\ ${ }^{3}$ Department of Law, Faculty of Law, Buton Muhammadiyah University, Baubau, Indonesia \\ ${ }^{4}$ Department of Development Economic, Faculty of Economic, Universitas Halu Oleo, Kendari, Indonesia \\ "Corresponding author. Email: rudiabdullah@umbuton.ac.id
}

\begin{abstract}
This study aims to determine the Analysis of Inventory Control Using the Economic Order Quantity Method in CV. Melai Fresh, data collection is done by using a preliminary survey, literature study and field survey. Data analysis uses descriptive analysis. The results of this study indicate that the number of purchases of 240 $\mathrm{ml}$ cup packaging materials and cartons according to EOQ calculation is 17,691,504. $240 \mathrm{ml}$ cups and carton boxes are 368,573 cartons. Savings on inventory costs of 13.84\% are around Rp 57,645 for $240 \mathrm{ml}$ cup packaging raw materials per year and cardboard box packaging raw materials around $5.88 \%$. The safety stock amounted to 447,306, $240 \mathrm{ml}$ cup packaging and carton boxes around 9,319 cartons, with ordering frequency as much as 15 times a year. In addition, it was found that a maximum inventory of 1,884,697 cups and 34,295 carton boxes with reorder points of 860,088 cups and 17,919 cartons.
\end{abstract}

Keywords: Inventory Control, Economic Order Quantity Method, descriptive analysis

\section{INTRODUCTION}

Nowadays the development of the business world in Indonesia is starting to show quite rapid progress. This is evidenced by the emergence of various types of businesses that are scattered throughout Indonesia, ranging from small businesses owned by individuals to companies that have been established by having quite a number of subsidiaries. Thus, the competition between companies cannot be avoided, for that every company must be good at racking their brains in order to win the competition and achieve the company's true goal of achieving maximum profits. Furthermore, companies must be able to improve performance, especially in the production process so as to produce quality products and meet consumer expectations. A good production process requires a balance between factors of production, which include: raw materials, capital, machinery, methods, and human resources. Special raw materials are often an important factor, because the supply of raw materials is a major element in the smooth production process [1]. For that every company must have a good raw material needs planning and must be aligned with every element in the company without exception.

We know that every company has different ways to manage raw material inventory. Starting from the number of units of raw materials, time of use, as well as the total cost to purchase raw materials. But apart from that every company certainly needs the proper management of raw material inventory. Without proper management of raw material inventory, the company cannot carry out good production activities. Also, be aware, if the supply of raw materials is carried out in excessively large quantities over stock will cause some losses.

The first loss is the storage costs borne by the company will be even greater, besides that the company must bear the risk of damage in storage. The second loss is that the company must prepare a large enough fund to purchase raw materials [2]. Therefore, the supply of raw materials in an amount that is too large will cause the allocation of capital for investment in other fields will be reduced. In other words it can be mentioned that the amount of raw material inventory that is too large will actually be a barrier from the progress of other fields in the company.

Max O. Siwi in his research found the results of the research namely The conclusions in this study are: The company's raw material inventory from 2008 to 2010 each year has increased significantly; The results obtained with using the Economic Order Quantity (EOQ) method, the costs incurred by the company are less than the company's available policies; Economic Order Quantity (EOQ) method, is one of the right methods in the procurement of company inventory.

As for some disadvantages, if the supply of raw materials is carried out in quantities that are too small out of stock, it will hamper the production process [3]. Inventories of raw materials in quantities that are too small sometimes can not meet the needs of companies to carry out the production process. If the company runs out of raw materials, the implementation of the production process cannot run smoothly and consequently the quality of the final product will be low. In addition, the supply of raw materials in relatively small quantities will lead to a greater frequency of purchasing raw materials, so that the ordering costs borne by the company will be even greater.

In conjunction with the overall level of company efficiency, the activity of purchasing raw materials needs to be planned 
using appropriate methods so that the company avoids cost waste and the company can operate more efficiently in the future. One method that is quite efficient in managing raw material inventory control is the Economic Order Quantity (EOQ) method [4]. The Economic Order Quantity (EOQ) method is one of the methods most often applied to know the best amount of raw material inventory needed by a company to maintain smooth production in an efficient cost. This method is often used because it is easy to implement and is able to provide the best solutions for companies, this is evidenced by using the Economic Order Quantity (EOQ) method, not only is the amount of inventory that is most efficient for the company, but also the costs to be incurred by the company its raw material inventory is calculated by (Total Inventory Cost) and the most appropriate time to make a repurchase (calculated by Re-order Point). CV. Melai Fresh is a family business that is engaged in trading business, products sold are mineral water, and the market is all over Southeast Sulawesi. So far the company has not used the EOQ method in the procurement of inventory. So based on the background described above, the authors are interested in conducting research with the title "Analysis of Inventory Control Using the Economic Order Quantity Method in CV. Melai Fresh ". Writing the formulation of the problem used by the author as a reference in order to conduct research. Therefore, the authors want to raise the problem as follows:

a. What is the need for economical and optimal raw materials in the CV. Melai Fresh if calculated using the Economic Order Quantity method?

b. What is the amount of safety stock needed by CV. Melai Fresh if calculated using the Economic Order Quantity method?

c. When the CV. Melai Fresh does places an order (Reorder Point) back in inventory if using the Economic Order Quantity method?

Then, the research objectives are:

a. To find out the economical and optimal amount of raw materials provided by CV. Melai Fresh.

b. Knowing the amount of safety stock needed by CV. Melai Fresh.

c. Know the time of re-order (Re-order Point) inventory of CV. Melai Fresh.

\section{METHOD}

The types of data used in this study are as follows Qualitative Data. Qualitative data from this study are data obtained from CV. Melai Fresh in the form of information both in oral and written form. This qualitative data is like the history of CV. Melai Fresh, organizational structure and job descriptions of each employee who works on the CV. Melai Fresh. Quantitative data in this study were sourced from inventory reports on CV. Melai Fresh.

Source of data used in this study are primary data and secondary data. In this study the primary data used are inventory data and all parties who have a role in inventory valuation on the CV. Melai Fresh. In this research the secondary data used is in the form of literature studies, economic magazines, and other documentation information that can be retrieved through the on-line system (internet).
The population used in this study is inventory data with the Economic Order Quantity method on the CV. Melai Fresh. The sample in this study is the Economy Order Quantity inventory data on CV. Melai Fresh in 2017.

The method used to collect various data needed in this study are: Preliminary observations, namely the initial steps to find research titles and problems that can be raised as research material by reading the Journal or through other scientific papers [5]. After determining the research title of the research and the issues raised in the study through journals, the next step is to find the right research object and in accordance with the research title. Literature Study, namely with a method to obtain information from theories by studying and taking notes from literature books, magazines, journals, and other information materials related to the material discussed by the author [6]. Field Observation, which is a method of collecting data where the researcher makes observations directly to the place of the object under study [7]. Data analysis method is a method used to make a systematic, factual and accurate picture of an object to be studied [8]. Data analysis methods used are as follows.

\subsection{Determine Economics Order Quantity (EOQ)}

EOQ is the number of orders that can minimize the total cost of inventory, so the cost calculation is only based on costs that affect orders and purchases, namely total order costs and total storage costs. By using the following formula [9]:

$$
Q *(E O Q)=\sqrt{\frac{2 D S}{C}}
$$

Where, $\mathrm{Q} *=$ the quantity of goods at each order, $\mathrm{D}=$ Number of requests for raw materials in a period, $\mathrm{S}=$ Cost every time you order, and $\mathrm{C}=$ Storage cost per unit.

\subsection{Determine the Total Inventory Cost}

The total inventory cost is the sum of the cost of storing and ordering costs. The minimum total inventory cost will be reached when the cost of storing equals the cost of the message. At the time of minimum total inventory costs, the order amount can be said to be the most economical order number (EOQ). To determine the total inventory cost, the following formula is used [9]:

$$
T C=\frac{D}{Q} S+\frac{Q}{2} H
$$

Where, $\mathrm{TC}=$ Total Inventory Cost, $\mathrm{Q}=$ Number of items per order, $\mathrm{D}=$ Annual demand for supplies, in units, $\mathrm{S}=$ Order fee for each order, and $\mathrm{H}=$ Storage cost per unit.

\subsection{Determine Safety Stock}

In determining the cost of the savior inventory used statistical analysis, namely by considering the deviations that have occurred between the estimated uses of raw materials with actual use, so that the standard deviation is known. The standard deviation formula is as follows [10]: 


$$
S D=\sqrt{\sum \frac{(X-\bar{X})^{2}}{N}}
$$

Where, $\mathrm{SD}=$ Standard Deviation, $\mathrm{X}=$ Real Use, $\mathrm{X}=$ Estimated Usage, and $\mathrm{N}=$ Amount of Data. Assuming that the company uses $5 \%$ deviation and uses one side of the normal curve (the value can be seen in the standard table = $1.65)$, the Safety Stock calculation is as follows [11]:

$$
S S=1.65 \times S D
$$

Where, $\mathrm{SS}=$ Safety Stock, and SD $=$ Standard Deviation.

\subsection{Re-order Point}

Re-order Points can be calculated by adding up the need for raw materials during Lead Time plus the amount of safety stock inventory. So Re-order Points can be calculated by the formula [11]:

$$
R O P=(d x L)+S S
$$

Where, ROP $=$ Re-order Point, $d=$ level of need, $\mathrm{L}=$ Lead Time, and SS = Safety Stock.

\section{RESULTS AND DISCUSSION}

So far, CV. Melai Frash still does not use the EOQ method to control its inventory and only performs inventory calculations in a simple way, namely ordering raw materials based on the number of production requests, and ordering is done every 14 days, so that there is often excess or lack of raw materials. Therefore, certain accurate calculations are needed in determining inventory levels, one of which uses the calculation of Economic Order Quantity (EOQ). In this study, EOQ calculations using data from the last 3 years, from 2015-2017. Data on raw material needs for the past 3 years is as follows:

Table 1 The need for $240 \mathrm{ml}$ cup raw materials and cardboard boxes on CV Melai Fresh

\begin{tabular}{|clrc|}
\hline Year & \multicolumn{1}{|c}{ Raw Materials } & Packaging Needs of Raw Materials Per Year (unit) & Frequency Booking \\
\hline \multirow{2}{*}{2015} & Cup 240 ml & 17.686 .176 & 21 \\
\cline { 2 - 4 } & Cardboard Box & 368.462 & 21 \\
\hline \multirow{2}{*}{2016} & Cup 240 ml & 17.691 .456 & 21 \\
\cline { 2 - 4 } & Cardboard Box & 368.572 & 21 \\
\hline \multirow{2}{*}{2017} & Cup 240 ml & 17.691 .504 & 21 \\
\cline { 2 - 4 } & Cardboard Box & 368.573 & 21 \\
\hline
\end{tabular}

Ordering of raw materials is done 21 times per year with a lead time of 7 days. Every year these conditions are carried out routinely without considering changes in the environment or production conditions in the company. Ordering costs incurred on the CV. Melai Fresh fluctuates

\begin{tabular}{|c|c|c|}
\hline Year & Product & Cost Per Message (S) (IDR) \\
\hline \multirow[t]{2}{*}{2015} & Cup $240 \mathrm{ml}$ & 17.686 .176 \\
\hline & Cardboard Box & 368.462 \\
\hline \multirow[t]{2}{*}{2016} & Cup $240 \mathrm{ml}$ & 17.691 .456 \\
\hline & Cardboard Box & 368.572 \\
\hline \multirow[t]{2}{*}{2017} & Cup $240 \mathrm{ml}$ & 17.691 .504 \\
\hline & Cardboard Box & 368.573 \\
\hline
\end{tabular}
every year. The booking fees are as follows:

Table 2 Cost of ordering raw materials on CV Melai Fresh

Fees included in the booking fee are telephone fees and administration fees. The type of cost is calculated to determine how much savings will be obtained by using the
EOQ method. Storage costs incurred on the CV. Melai Fresh fluctuates every year. The storage costs are as

\begin{tabular}{|c|c|c|}
\hline Year & Product & Cost Per Message (H) (IDR) \\
\hline \multirow[t]{2}{*}{2015} & Cup $240 \mathrm{ml}$ & 3.69 \\
\hline & Cardboard Box & 177.05 \\
\hline \multirow[t]{2}{*}{2016} & Cup $240 \mathrm{ml}$ & 4.09 \\
\hline & Cardboard Box & 196.53 \\
\hline \multirow[t]{2}{*}{2017} & Cup $240 \mathrm{ml}$ & 4.50 \\
\hline & Cardboard Box & 216.07 \\
\hline
\end{tabular}
follows:

Table 3 Storage costs for CV Melai Fresh

Costs included in the storage costs on the CV. Melai Fresh is the cost of electricity, the cost of supervision and maintenance. Where from year to year it has increased due to high consumer demand. Company Policy Calculations that occur in the CV. Melai Fresh fluctuates every year. The Company Policy Calculation is as follows: 
Table 4 Company policy calculation on CV Melai Fresh

\begin{tabular}{|c|c|c|c|c|}
\hline Year & Product & Needs of Raw Materials Per Year (unit) & Frequency & Average Order Amount \\
\hline & & (D) & (f) & $\mathrm{Q}=(\mathrm{d} / \mathrm{f})$ \\
\hline \multirow[t]{2}{*}{2015} & Cup $240 \mathrm{ml}$ & 17.686.176 & 21 & 842.199 \\
\hline & Cardboard Box & 368.462 & 21 & 17.546 \\
\hline \multirow[t]{2}{*}{2016} & Cup $240 \mathrm{ml}$ & 17.691 .456 & 21 & 842.450 \\
\hline & Cardboard Box & 368.572 & 21 & 17.551 \\
\hline \multirow[t]{2}{*}{2017} & Cup $240 \mathrm{ml}$ & 17.691 .504 & 21 & 842.453 \\
\hline & Cardboard Box & 368.573 & 21 & 17.551 \\
\hline
\end{tabular}

The table above shows that there are purchases of raw materials made by CV. Melai Fresh in 2015 to 2017. In addition, supplies that need to be done every time the message is not too different from year to year. That is because the number of requests that did not increase significantly and the number of order frequencies that did not change each year. The order frequency is 21 times. Data obtained when using calculations with the EOQ method on the CV. Melai Fresh is as follows:

Table 5 Calculations according to the EOQ method on CV Melai Fresh

\begin{tabular}{|clrc|}
\hline Year & \multicolumn{1}{c}{ Product } & Order Amount & Frequency \\
\hline & & $\mathrm{EOQ}=\sqrt{2} \times \mathrm{D}$ x S / H & F=D/EOQ \\
\hline \multirow{2}{*}{2015} & Cup 240 ml & 1.492 .031 & 12 \\
\cline { 2 - 4 } & Cardboard Box & 25.164 & 15 \\
\hline \multirow{2}{*}{2016} & Cup 240 ml & 1.492 .084 & 12 \\
\cline { 2 - 4 } & Cardboard Box & 24.697 & 12 \\
\hline \multirow{2}{*}{2017} & Cup 240 ml & 1.437 .411 & 15 \\
\cline { 2 - 4 } & Cardboard Box & 24.977 & 15 \\
\hline
\end{tabular}

Based on the above, the number of orders is more than the company policy. The frequency of ordering is rarely done by CV. Melai Fresh from the beginning 21 times per year to only 12 and 15 times in one year. Calculation of total inventory costs using the EOQ method aims to find the value of efficiency that can be generated when optimizing the amount of company inventory. The data obtained when using the calculation of inventory cost savings in CV. Melai Fresh is as follows:

Table 6 Savings in inventory cost on CV Melai Fresh

\begin{tabular}{|clccc|}
\hline Year & \multicolumn{1}{c|}{ Product } & Company Policy (IDR) & EOQ (IDR) & Savings (IDR) \\
\hline \multirow{2}{*}{2015} & Cup 240 ml & 6.428 .274 & 5.503 .530 & 924.744 \\
\cline { 2 - 5 } & Cardboard Box & 4.748 .274 & 4.455 .428 & 292.846 \\
\hline \multirow{2}{*}{2016} & Cup 240 ml & 7.134 .643 & 6.109 .114 & 1.025 .529 \\
\cline { 2 - 5 } & Cardboard Box & 5.139 .643 & 4.853 .722 & 285.920 \\
\hline \multirow{2}{*}{2017} & Cup 240 ml & 7.416 .131 & 6.470 .438 & 945.693 \\
\cline { 2 - 5 } & Cardboard Box & 5.736 .131 & 5.396 .719 & 339.412 \\
\hline
\end{tabular}

The table above shows that the control of raw material inventory in CV. Melai Fresh is considered feasible to be applied according to the EOQ method. The company can save more money on raw material supplies, especially 240 $\mathrm{ml}$ cup packaging and carton boxes. According to Sampeallo (2012), the calculation of total inventory costs using the EOQ method is able to provide cost efficiencies. This is because by using the EOQ method, there will be obtained a more optimal number of ordering frequencies so that it can reduce ordering costs and inventory storage costs. $\mathrm{CV}$. Melai Fresh has been budgeting for safety stock for raw material packaging is not too high and only uses estimates because raw materials are considered easy to obtain at any time. The safety stock of the $240 \mathrm{ml}$ cup packaging that has been provided by the company has only been based on estimates of around 150,000 cups, while for carton boxes around 6500 cartons. Furthermore, the magnitude of the safety stock will be calculated using calculations through deviation analysis.
In the analysis of deviations, the company must also determine how far the conditions of raw materials are still acceptable. CV. Melai Fresh determines the acceptable tolerance limit of $5 \%$ and the service ratio is $95 \%$ so that the safety factor is 1.65 . Calculation of safety stock according to the EOQ method with deviation analysis for $240 \mathrm{ml}$ cup packaging and cardboard boxes in 2015 was 447,382 cups and 9,320 cartons, in 2016 as many as 447,249 cups and 9,318 cartons, in 2017 there were 447,286 cups and 9,318 cartons.

So far, CV. Melai Fresh determines the maximum inventory for packaging raw materials based on the average amount of raw materials ordered plus safety stock. The purpose of doing a maximum inventory calculation is so that the company can avoid the occurrence of shortages or excess inventory, because both of these are very disruptive to the production and distribution processes and can have an impact on company losses Maximum inventory using EOQ can be seen in. 
Table 7 Calculation of maximum inventory on CV Melai Fresh

\begin{tabular}{|llrrr|}
\hline Year & \multicolumn{1}{c}{ Product } & Safety Stock & EOQ (IDR) & \multicolumn{1}{c|}{ Maximum Inventory } \\
\hline & & & & (EOQ+Safety Stock) \\
\hline \multirow{2}{*}{2015} & Cup 240 ml & 447.382 & 1.492 .031 & 1.939 .413 \\
\cline { 2 - 5 } & Cardboard Box & 9.320 & 25.164 & 34.485 \\
\hline \multirow{2}{*}{2016} & Cup 240 ml & 447.249 & 1.492 .084 & 1.939 .333 \\
\cline { 2 - 5 } & Cardboard Box & 9.318 & 24.697 & 34.015 \\
\cline { 2 - 5 } & Cup 240 ml & 447.286 & 1.437 .411 & 1.884 .697 \\
\hline
\end{tabular}

Reorder Points (ROP) are used to monitor inventory items, so that when ordering goods returned ordered items will arrive on time [11]. CV. Melai Fresh schedules reorder points based only on the time and estimated number of consumer requests, so re-ordering will be done when inventory in the warehouse starts to feel a little amounting to around 550,000 for cup packaging and 15,000 for carton packaging. Table 4.8 shows the reorder point calculation according to the EOQ method.

Table 8 Reorder point calculation on CV Melai Fresh

\begin{tabular}{|c|c|c|c|c|c|c|}
\hline Year & Product & D & Q (day) & Lead Time & $S S$ & ROP \\
\hline \multirow{2}{*}{2015} & Cup & 17.686 .176 & 58.954 & 7 & 447.382 & 860.059 \\
\hline & Cardboard Box & 368.462 & 1.228 & 7 & 9.320 & 17.918 \\
\hline \multirow[t]{2}{*}{2016} & Cup & 17.691 .456 & 58.972 & 7 & 447.249 & 860.050 \\
\hline & Cardboard Box & 368.572 & 1.229 & 7 & 9.318 & 17.918 \\
\hline \multirow[t]{2}{*}{2017} & Cup & 17.691 .504 & 58.972 & 7 & 447.286 & 860.088 \\
\hline & Cardboard Box & 368.573 & 1.229 & 7 & 9.318 & 17.919 \\
\hline
\end{tabular}

\section{CONCLUSIONS}

The number of purchases of $240 \mathrm{ml}$ cup packaging materials and cartons according to EOQ calculation is 17,691,504 cups $240 \mathrm{ml}$ and carton boxes are 368,573 cartons. Savings on inventory costs of $13.84 \%$ are around $\mathrm{Rp} 57,645$ for 240 $\mathrm{ml}$ cup packaging raw materials per year and cardboard box packaging raw materials around $5.88 \%$. The safety stock amounted to $447,306,240 \mathrm{ml}$ cup packaging and carton boxes around 9,319 cartons, with ordering frequency as much as 15 times a year. In addition it was found that a maximum inventory of $1,884,697$ cups and 34,295 carton boxes with reorder points of 860,088 cups and 17,919 cartons.

\section{REFERENCES}

[1] Jusuf, Al Haryono. 2005. Dasar-Dasar Akuntansi. BPFE. Yogyakarta

[2] Mardiasmo. 2004. Akuntansi Keuangan Dasar I. Edisi tiga, jilid satu. BPFE. Yogyakarta.

[3] Max O. Siwi, 2004 Analisis Pengendalian persediaan bahan baku dengan metode EOQ Pada Produk Obat Anti Nyamuk Bakar Manguni. Diterbitkan : Program Studi Admninistrasi Bisnis Fisip Unsrat

[4] Rangkuti, frieddy. 2007. Manajemen Persediaan Aplikasi Di Bidang Bisnis. Raja Grafindo Persada. Jakarta
[5] Ghozali, I. (2011). Aplikasi Analisis Multivariate dengan Program IMB SPSS 19. Semarang: Badan Penerbit Universitas Diponegoro.

[6] Sugiono. (2013). Statistik untuk Penelitian. Bandung : Alfabeta

[7] R Abdullah, D Mahmuda, E Malik, ET Pratiwi, M Rais, A Dja'wa Dan LOD Abdullah (2019) The Influence of Environmental Performance, Environmental Costs, and Firm Size on Financial Performance with Corporate Social Responsibility as Intervening Variables (Empirical Study on Manufacturing Companies Listed on the Indonesia Stock Exchange 2014-2018)

[8] Abdullah, R., Malik, E., Pratiwi, E. T., Abdullah, L. O. D., \& Sulili, A. (2019, February). Influence of corporate social responsibility on company performance. In IOP Conference Series: Earth and Environmental Science (Vol. 235, No. 1, p. 012004). IOP Publishing.

[9] Render, Barry; Heizer, Jay. 2005. Manajemen Operasi. Edisi Ketujuh. Bandung: Salemba Empat.

[10] Assauri, Sofyan. 2016. Manajemen Produksi dan Operasi. Edisi Keempat. Jakarta: FE UI.

[11] Ilham Alamsya, Apriatni EP , Andi Wijayant. 2013, Analisis pengendalian persediaan bahan baku tembakau Dengan menggunakan metode EOQ guna mencapai efisiensi total biaya Persediaan bahan baku pada pr. Gambang sutra kudus. Diterbitkan : Diponegoro Journal Of Social And Politic Tahun 2013, Hal. 1-10 http://ejournal-s1.undip.ac.id/index.php 